\title{
Combined influences of iron-oxides and micropores on reddish coloration of alkali feldspars in granitic rocks
}

\author{
Satoshi Nakano, ${ }^{1,2}$ \\ Kuniaki Makino ${ }^{3}$, Izumi Yoshida ${ }^{4}$, \\ Kanae Maniwa, \\ Kazuhiko Sawada 6 , \\ Fuko Sakashita ${ }^{7}$ and \\ Toshio Kohno ${ }^{8}$
}

Received August 24, 2018

Accepted July 1, 2019

Department of Natural Science, Faculty of Education, Shiga University, Hiratsu 2-5-1, Otsu 520-0862, Japan

2 Present address: Lake Biwa Museum, Oroshimo 1091, Kusatsu 525-0001, Japan

Department of Geology, Faculty of Science, Shinshu University, Asahi 1-1-1, Matsumoto 390-8621, Japan

4 Rigaku Co. Ltd., Kiri 3-1-23, Matsumoto 390-0871, Japan

$5 \quad$ Mitsukuri Elementary School, Kowakicho 377, Higashi-oumi 527-0091, Japan

6 Ohgi Junior High School, Ohginosato 5-1-1, Otsu 520-0246, Japan

7 Marikoserigaya-cho 16-4, Suruga-ku, Shizuoka 421-0104, Japan

8 Tanakami-Shinme, Otsu 520-0864, Japan

Corresponding author: S. Nakano,

nakano@edu.shiga-u.ac.jp

\begin{abstract}
The international color parameters $\left(L^{*}, a^{*}\right.$, and $\left.b^{*}\right)$ of four granite alkali feldspars, determined by a new method using a scanner and personal computor system show a successive variation of reddish colors. Small reddish particles and whitish micropores were observed using a binocular microscope. Raman spectroscopy showed that the common reddish particles are hematite in all four feldspar samples, and showed maghemite in the G175 feldspar. Distributions of Fe-oxide particles and micropores were assessed by electron microprobe mapping, and their area percentages in the feldspars were obtained using image processing. The results suggest that the size distribution and number density of both hematite and micropores control the reddish color variation in the alkali feldspars, with some additional influencing factors such as the presence of maghemite.
\end{abstract}

Key words: Alkali feldspar, reddening, granite, color measurement, EMPA, Raman spectroscopy, hematite, maghemite, micropore

\section{Introduction}

The occurrence of pink-red (hereafter, reddish) alkali feldspars to the naked eye is very common in granitic rocks (Smith, 1974; Smith and Brown, 1988; Putnis et al., 2007; Deer et al., 2001), and many of them have been used as ornament stones (e.g., Sekigahara Stone Company, 1998; Demarco et al., 2013). The cause of feldspar reddening in granitic rocks has been attributed to the presence of hematite as Fe-bearing reddish particles (Boone, 1969; Hofmeister and Rossman, 1983; Nakashima et al., 1992; Deer et al., 2001; Putnis et al. 2007; Engvik et al., 2008; Plümper and Putnis, 2009). These reddish colors have been well known to be products of hydrothermal reactions in feldspars through these studies. The geological significance of such feldspar reddening as hydrothermal events in the crust has been increasingly shown (Putnis et al., 2007; Engvik et al., 2008; Plümper and Putnis, 2009).

To date, the presence of hematite in reddish feldspars has been confirmed indirectly from geological and geochemical evidence (Boone, 1969) and directly by observations using a transmission electron microscope (TEM) (Nakashima et al., 1989; Engvik et al., 2008; Plümper and Putnis, 2009). However, color measurements have not been performed in these studies, and the factors controlling the reddish color variations have not been examined except for Nakashima et al. (1989). Nakashima et al. (1992) examined reddish color variations using granite blocks with a focus on color measurements, and elucidated that the granite reddish color variation is controlled by the contents mainly of hematite and subordinately of goethite and other Fe-bearing minerals. The color parameters of natural granite blocks in $\mathrm{Na}-$ kashima et al. (1992) were obtained from wide areas of $8 \mathrm{~mm}$ in diameter. After the study, any color variation 
has not been investigated for reddish feldspars.

In this context, we have employed a new approach to elucidate the reason of color variations of reddish alkali feldspars in granites. Color measurements in this study were made for each micron-scale area only in alkali feldspars much more finely than Nakashima et al. (1992). Other investigations to elucidate the reason of their reddish color variations were performed using a petrographic microscope, a binocular microscope, an electron microprobe analyzer (EMPA), a field emissionscanning electron microscope (FE-SEM) and a Raman spectrometer. This paper describes such data obtained by these methods, which should provide new insights for understanding reddish color variations in granitic alkali feldspars.

\section{Samples of reddening alkali feldspars}

Alkali feldspars in various granitic rocks show a spectrum of reddish colors to the naked eye (visually) ranging from pale-pink to deep red (Hofmeister and Rossman, 1983; Smith and Brown, 1988; Sekigahara Stone Company, 1998; Demarco et al., 2013; Gaeta et al., 2013). Such visually reddish colors are very closely related to some other color tints such as brown or orange. Brown and orange colors are relatively more intensive in yellowish tints ( $b^{*}$ values as introduced later) than pink to red colors (see, No. 31-36 in Table 1 of Nakano et al. (2012)). Thus, the term "reddish" in this paper means that its visual colors are more or less affected by brown or orange colors.

Eight "fresh" granite samples containing visually reddish alkali feldspars with different tints were selected from many granite stones on the basis of obtained color parameters (Sekigahara Stone Company, 1998) in a preliminary study (see, Figure 19 of Nakano et al., 2012). The term "fresh" in this paper means that the granites are apparently free of weathering. It was finally shown in the study (Nakano et al., 2012) that the three samples (G81, G101 and G175) show a successive color variation consistently with that of synthetic mixtures of hematite and alumina by Nakashima et al. (1992), which is used as the standard or reference color variation (calibration line) in this study. These three samples were also used in this study. In addition, the Man-nari granite from Okayama Prefecture, southwest Japan, which is famous for containing pink alkali feldspar in Japan and was preliminarily examined by Yoshida et al. (2010), was added in this study, because its visually reddish colors are intermediate between those of the G101 and G175 feldspar (Fig. 1). These four granites are apparently very fresh to the naked eye, and appear not to have undergone weathering alteration (Fig. 1). For comparison, moreover, a whitish feldspar in the G125 granite (Sekigahara Stone Company, 1998) was subjected to color measurements (Fig. 1).

\section{Color parameters}

Among several international color spaces, the L*-a*b* color space (Hunt, 1980) is employed in this study, which has been commonly used in recent color measurements of geological materials (Nagano and Nakashima, 1989; Nakashima et al., 1992; Manaka et al., 2012). L* (brightness) varies from 0 (white) to 100 (black). The increase of $\mathrm{a}^{*}$ values from an origin $\left(\mathrm{a}^{*}=\right.$ 0 ) means the increase of red tint, and their decrease means the increase of green tint. The increase of $b^{*}$ values from an origin $\left(b^{*}=0\right)$ means the increase of yellow tint, and their decrease means the increase of blue tint. The color parameters of $a^{*}$ and $b^{*}$ obtained from the alkali feldspars are plotted in Figure 2. In Figure 2, the color parameters of the white G125 feldspar measured for comparison is also plotted.

Nakano et al. (2012) compared international color parameters, $\mathrm{a}^{*}$ (reddish-green) and $\mathrm{b}^{*}$ (yellow-blue), of the aforementioned selected eight reddish alkali feldspars. And, using the G48 alkali feldspar showing a larger color variation among them, its color data obtained by the following four different methods were compared: (1) by a personal computer (PC) and a personal scanner (SC) (hereafter, PC\&SC method) (Nakano et al., 2012), (2) by a portable CCD spectrometer (Nakano and Makino, 2010; Kohno et al., 2011), (3) by a micro spectrometer of Carl Zeiss MPM, (4) by a chromameter of Konica-Minolta CR-100 that was used to calibrate color parameters obtained by the PC\&SC method. The color data obtained by the four methods were principally consistent each other: namely, their slopes (hereafter, S) of fitting lines for $\mathrm{a}^{*}$ and $\mathrm{b}^{*}$ plots

Fig. $1(\rightarrow)$. (a) Colors of four reddish alkali feldspars in the studied granite chips. Rectangles indicate the areas selected for color measurement, and $1.5 \times 1.5 \mathrm{~mm}$ squares show areas of EMPA mapping analyses shown in Fig. 3 . Scale bars are $1 \mathrm{~cm}$. (b) Images obtained by a scanner for the areas that include the rectangular sections shown in (a). Rectangles show the same areas as in (a) and their areas are $1.0 \times 0.5 \mathrm{~mm}$ except for the slightly larger Man-nari area. One pixel measures $0.125 \times$ $0.125 \mathrm{~mm}$ except for the Man-nari sample. The granite names (G101, USA; G175, USA; G81, Spain) are according to the stone names from the Sekigahara Stone Company (1998). 


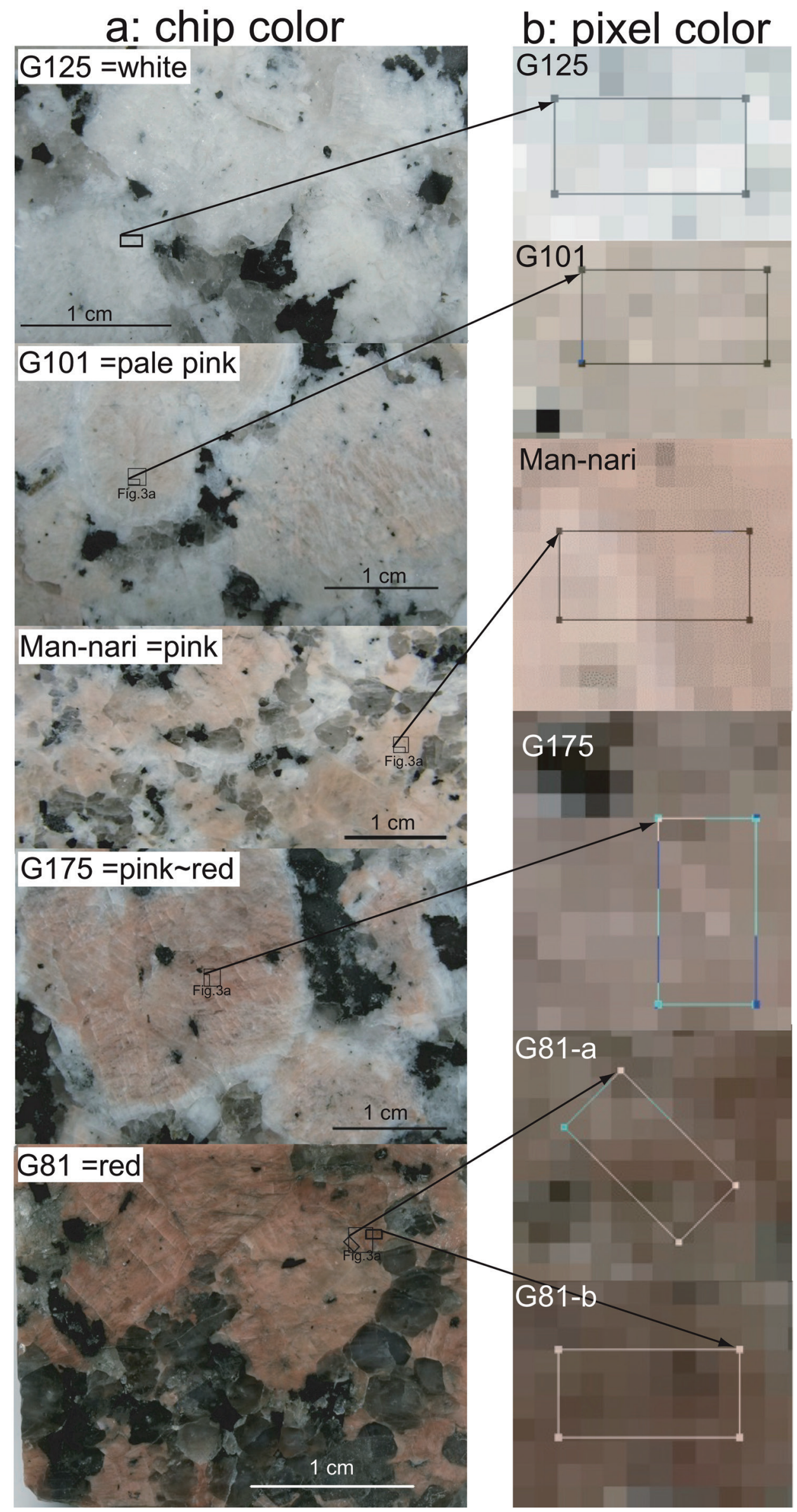




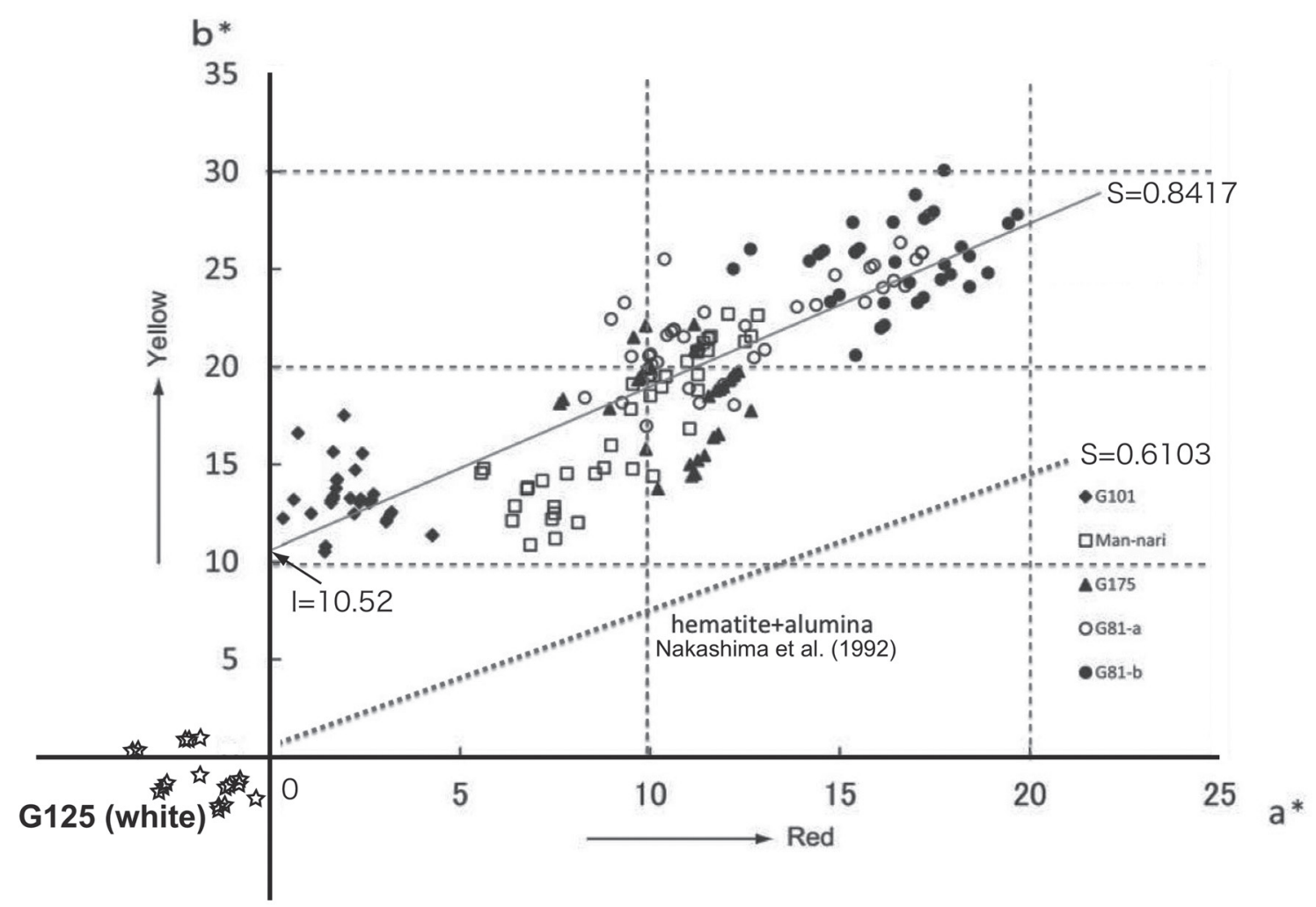

Fig. 2. Color variation of the four reddish alkali feldspars, showing variations within each grain from pale pink to red. Each individual $\mathrm{a}^{*}$ and $\mathrm{b}^{*}$ value is for a single pixel with pixel sizes shown in Figure $1 \mathrm{~b}$. One pixel measures $0.125 \times 0.125 \mathrm{~mm}$ except for the Man-nari sample (see Table 1). The color variation range of the G125 white alkali feldspar is shown as an ellipse for reference. $\mathrm{S}$ = slope and $\mathrm{I}=$ intersection.

are not so deviated irrelevantly to the differences of light sources and measuring methods as shown in Table 1 , although some differences are recognized between their intersections to the $\mathrm{b}^{*}$ axis (hereafter, I). Thus, the PC\&SC method was employed in this study as described below.

\section{Analytical methods}

\section{Color measurements}

The PC\&SC method has advantages of easy, rapid and detailed color measurements area by area within a feldspar grain. In this study, this method was employed from these advantages on the basis of Nakano et al. (2012) mentioned above. In the present color measurements, a SC of Epson PA-850 was used. Color image scans by the $\mathrm{SC}$ were made for polished surfaces of the granite samples under the condition of 200 dpi that corresponds to one pixel size of $0.125 \mathrm{~mm} \times 0.125 \mathrm{~mm}$. The 200 dpi scan was employed for using the SC, after comparing color parameters of the G175 alkali feldspar obtained by different resolving powers or dpi values (Table 2). Color images obtained by the SC were processed by a Mac computer (Mac OS 10.3.9) using a software, Adobe Photoshop Elements (Ver.3). Color measurements for the SC color images were made for each pixel using a software of Mac Digital Color Meter, This software provides $\mathrm{L}^{*}, \mathrm{a}^{*}$ and $\mathrm{b}^{*}$ parameters directly on a Mac PC.

\section{Electron microprobe analyses and Raman spec- troscopy}

An electron microprobe analyzer (EMPA), JXA$8800 \mathrm{M}$ type of JEOL at Shiga University, was used for determining chemical compositions of alkali feldspars and for mapping analyses of them. Analyses by a $50 \mu \mathrm{m}$ beam in diameter were made to obtain local bulk compositions (analysis numbers $=200$ for each area of each sample), whose averages have been well accepted as approximately showing bulk compositions (e.g., Lee and Parsons, 1997; Nakano et al., 2005, 2014). A focused beam was applied for mapping analyses. All EMPA analyses were done under the condition of $15 \mathrm{kV}$. A probe current was set as $20 \mathrm{nA}$ for quantitative analyses, and as $50 \mathrm{nA}$ for mapping analyses. These analytical methods are principally the same as the cases of Nakano et al. $(2002,2005,2014)$, except for the difference of pixel numbers in mapping. EMPA mapping was made 
Table 1. Comparison of color data obtained by different methods for the G48 granite alkali feldspar (Nakano et al., 2012).

\begin{tabular}{llr}
\hline \multicolumn{1}{c}{ Obtained data } & Slope & Intersection \\
\hline (a) Method (1)* data by PC\&SC & 0.640 & 13.47 \\
(b) Method (1)* data calibrated** & 0.642 & 7.11 \\
(c) Method (2)* data by fluorescent light & 0.700 & 8.24 \\
(d) Method (2)* data by incandescent light & 0.830 & 2.68 \\
(e) Method (3)* data by a micro-spectrometer & 0.741 & 9.31 \\
\hline
\end{tabular}

* Methods (1), (2) and (3) are interpreted in the text.

** Corresponding light source is D65. The detail is in Nakano et al. (2012).

Table 2. Values of $\mathrm{L}^{*}, \mathrm{a}^{*}$ and $\mathrm{b}$ * due to the difference of resolving power for the G175 alkali feldspar.

\begin{tabular}{cccccc}
\hline $\begin{array}{c}\text { resolving power } \\
(\mathrm{dpi})\end{array}$ & $\begin{array}{c}\text { size of pixel } \\
(\mathrm{mm})\end{array}$ & $\begin{array}{c}\text { number of } \\
\text { measurement }\end{array}$ & $\begin{array}{c}\mathrm{L}^{*} \\
\text { (average) }\end{array}$ & $\begin{array}{c}\mathrm{a}^{*} \\
\text { (average) }\end{array}$ & $\begin{array}{c}\mathrm{b}^{*} \\
\text { (average) }\end{array}$ \\
\hline 200 & 0.125 & 8 & 57.6 & 8.7 & 14.0 \\
300 & 0.08 & 12 & 58.8 & 8.0 & 13.8 \\
400 & 0.06 & 16 & 57.6 & 8.7 & 13.6 \\
600 & 0.04 & 23 & 57.6 & 8.2 & 14.3 \\
\hline
\end{tabular}

Table 3. Values of $\mathrm{L}^{*}, \mathrm{a}^{*}$ and $\mathrm{b}^{*}$ of the alkali feldspars obtained under the settled conditions.

\begin{tabular}{lcccc}
\hline sample & no. $\left(\right.$ pixel $\left.^{*}\right)$ & $\mathrm{L}^{*}$ & $\begin{array}{c}\text { average } \\
\mathrm{a}^{*}\end{array}$ & $\mathrm{~b}^{*}$ \\
\hline G101 & 32 & 80.9 & 2.1 & 13.2 \\
Man-nari & 40 & 80.8 & 9.3 & 16.7 \\
G175 & 32 & 61.4 & 11.1 & 18.2 \\
G81-a & 39 & 45.2 & 12.5 & 22.1 \\
G81-b & 32 & 36.4 & 16.5 & 25.4 \\
\hline
\end{tabular}

${ }^{\#}:$ pixel size $=125 \mu \mathrm{m}^{2}$

under the division or pixel numbers at $300 \times 300=$ 90,000. Obtained Fe-distribution maps (Fe-maps) and back-scattered electron images (BSIs) were subjected to image processing with a JEOL software (SP VIEW) to estimate quantities or proportions of $\mathrm{Fe}$-dots and micropores. Micropores were also observed by a FE-SEM, JSM-7600F, at Shinshu University. A software (Image J, $\mathrm{NIH}$ ) was used to estimate sizes and number densities of Fe-bearing particles and micropores on secondary electron images (SEIs) and BSIs.

Raman spectra were acquired with a micro Raman spectrometer (JASCO NRS-3100) at Shinshu University to identify small reddish Fe-bearing particles in the feldspars. A $532 \mathrm{~nm}$ beam with a diameter of ca. $2 \mu \mathrm{m}$ was selected as the exciting source with a resolution of $3.5 \mathrm{~cm}^{-1}$. Raman scattering light was acquired with 5 seconds with 5 accumulations per spectrum segment, using the Spectro Maneger software of JASCO.

\section{Characterization of the feldspar color variation}

Figure $1 \mathrm{~b}$ shows color variations, pixel by pixel, on PC images for the G125 white alkali feldspar and four reddish alkali feldspars, which were transferred from color images scanned for the chip surfaces shown in Figure 1a. Individual areas for color measurements are shown by rectangles in Figure 1. Areas subjected to measurements were selected as representative or typical ones in the individual feldspars by visual observations of colors. Reddish colors are variable pixel by pixel and locally in individual alkali feldspars (Fig. 1).

Figure 2 and Table 3 show the reddish color variation through the four reddish alkali feldspars respectively. Figure 2 shows plots of $\mathrm{a}^{*}$ and $\mathrm{b}^{*}$ values of individual pixels in the four alkali feldspars with those in the G125 white feldspar. Individual fitting lines for the four samples show very different Ss and Is each other, which is a 
Table 4. Local bulk compositions of the alkali feldspars. Analyzed elements are Si, Al, Na, K, Ca, Ba and Fe, which are major and minor elements constituting alkali feldspars. Each total $\mathrm{wt} \%$ of obtained compositions is within the error of \pm 2 $\%$ and each sum value of atomic proportions calculated on the basis of $\mathrm{O}=8$ is within $\pm 1 \%$. The stoichiometry of the feldspar composition is nearly complete.

\begin{tabular}{|c|c|c|c|c|c|c|c|c|c|c|c|c|c|}
\hline & \multirow{2}{*}{$\begin{array}{l}\text { Number of } \\
\text { analyses }\end{array}$} & \multicolumn{8}{|c|}{ Average chemical compositions (wt $\%$ ) } & \multirow{2}{*}{$\begin{array}{l}\text { Or-Ab-An } \\
\text { composition }\end{array}$} & \multicolumn{2}{|c|}{$\mathrm{Fe}_{2} \mathrm{O}_{3}(\mathrm{wt} \%)$} & \multirow[b]{2}{*}{ maximum } \\
\hline & & $\mathrm{SiO}_{2}$ & $\mathrm{Al}_{2} \mathrm{O}_{3}$ & $\mathrm{Fe}_{2} \mathrm{O}_{3}$ & $\mathrm{CaO}$ & $\mathrm{Na}_{2} \mathrm{O}$ & $\mathrm{K}_{2} \mathrm{O}$ & $\mathrm{BaO}$ & Total & & average & minimum & \\
\hline G101 & 200 & 65.44 & 18.41 & 0.07 & 0.20 & 3.21 & 12.84 & 0.17 & 100.34 & $\mathrm{Or}_{72} \mathrm{Ab}_{27} \mathrm{An}_{09}$ & 0.07 & 0.00 & 1.36 \\
\hline \multirow{2}{*}{$\begin{array}{l}\text { Man-nari } \\
\text { G175 }\end{array}$} & 200 & 63.95 & 18.19 & 0.09 & 0.14 & 3.60 & 11.78 & 0.79 & 98.53 & $\mathrm{Or}_{68} \mathrm{Ab}_{31} \mathrm{An}_{0.7}$ & 0.09 & 0.00 & 1.06 \\
\hline & 200 & 64.99 & 18.41 & 0.06 & 0.13 & 2.40 & 14.11 & 0.44 & 100.54 & $\mathrm{Or}_{79} \mathrm{Ab}_{20} \mathrm{An}_{0.5}$ & 0.06 & 0.00 & 1.30 \\
\hline G81-a & 200 & 65.71 & 18.44 & 0.08 & 0.11 & 3.92 & 11.92 & 0.09 & 100.26 & $\mathrm{Or}_{66} \mathrm{Ab}_{33} \mathrm{An}_{05}$ & 0.08 & 0.00 & 0.82 \\
\hline G81-b & 200 & 64.71 & 18.22 & 0.45 & 0.12 & 3.10 & 13.05 & 0.08 & 99.73 & $0 \mathrm{r}_{73} \mathrm{Ab}_{26} \mathrm{An}_{0.5}$ & 0.45 & 0.01 & 3.22 \\
\hline
\end{tabular}

Table 5. Distribution modes of $\mathrm{Fe}_{2} \mathrm{O}_{3}$ content in EMPA local bulk compositions.

\begin{tabular}{lccccc}
\hline & (a) $\geqq 0.3 \mathrm{wt} \%$ & (b) $0.3-0.1 \mathrm{wt} \%$ & (c) $0.1-0.05 \mathrm{wt} \%$ & (d) $0.05-0.03 \mathrm{wt} \%$ & (e) $0.03 \mathrm{wt} \% \leqq$ \\
\hline G101 & 0.0 & 5.5 & 47.0 & 25.0 & 22.5 \\
Man-nari & 3.5 & 7.5 & 38.5 & 23.5 & 27.0 \\
G175 & 1.0 & 8.5 & 33.0 & 22.5 & 35.0 \\
G81-a & 2.5 & 9.5 & 33.0 & 19.0 & 36.0 \\
G81-b & $36.0(\%)$ & 47.5 & 14.0 & 2.0 & 0.5 \\
\hline
\end{tabular}

Numbers of EMPA local bulk analyses $=200$ for each feldspar

problem out of this study. In this study, a fitting line obtained through the four samples showing a successive variation of visually reddish colors is treated according to the preliminary study of Nakano et al. (2012) on the basis of the study of Nakashima et al. (1992). A straight line of $\mathrm{S}=0.8417$ is fitted for all the plots. The obtained $\mathrm{S}$ is approximately the same as that of reddish granite blocks obtained by Nakashima et al. (1992). Individual plots are much deviated from this line. This unevenness is quite different from the plots in Nakashima et al. (1992). This difference is derived from the difference between their measured areas. In Figure 2, the fitting straight line does not pass through the origin, which was already recognized irrelevantly from the difference of color measurement apparatus or methods in Nakano et al. (2012). Its I value of ca.10.5 in Figure 2 means some addition of yellow tint to the reddish colors.

\section{Fe-bearing reddish particles}

\section{Fe-content in feldspars}

Local bulk compositions of the same areas as those of color measurements were obtained by the method described already. Each average composition of the alkali feldspars is conveniently recognized as each bulk composition, which has been well accepted (e.g., Lee and Parsons, 1997; Nakano et al., 2005, 2014) (Table 4). In Table 4, minimum and maximum $\mathrm{Fe}_{2} \mathrm{O}_{3}$ contents are shown for each examined area of the four alkali feldspars, in addition to bulk (average) $\mathrm{Fe}_{2} \mathrm{O}_{3}$ contents. The chemical state of iron is generally represented as $\mathrm{Fe}^{+3}$ in hydrothermally reacted feldspars such as clouded and turbid ones (Deer et al. 2001; Nakano et al., 2005, 2014; etc.) so that $\mathrm{Fe}$ contents are represented as $\mathrm{Fe}_{2} \mathrm{O}_{3}$ in this paper.

Contents of $\mathrm{Fe}_{2} \mathrm{O}_{3}$ in feldspars are generally less than $0.3 \mathrm{wt} \%$, and many of them are less than $0.1 \mathrm{wt} \%$ in $\mathrm{Fe}_{2} \mathrm{O}_{3}$ (Deer et al., 2001; Nakano et al., 2005). Their average contents in Table 4 are consistent with this, except for the high content of the deeply reddish G81-b alkali feldspar. Local bulk analyses more concretely elucidate variations of $\mathrm{Fe}_{2} \mathrm{O}_{3}$ contents within the individual alkali feldspars as shown in Table 5, which principally correspond to the local (pixel by pixel) color variations shown in Figure 1. Most of $\mathrm{Fe}_{2} \mathrm{O}_{3}$ contents in the individual local bulk compositions are lower than $0.1 \mathrm{wt} \%$ through the feldspars, except for the deeply reddish G81-b.

The variation of average $\mathrm{Fe}_{2} \mathrm{O}_{3}$ contents through the four alkali feldspars in Table 4 are not consistent with the color variation in Figures 1 and 2 and Table 3: $\mathrm{Fe}_{2} \mathrm{O}_{3}$ contents of the three feldspars except for the G81 feldspar are nearly the same in spite of their color differences. This inconsistency is also recognized in Table 5. It should be noted, however, that their $\mathrm{Fe}_{2} \mathrm{O}_{3}$ contents are not related to the grain size distributions and number densities of Fe-bearing particles, which more or less affect feldspar reddish colors.

\section{Fe-distributions}

EMPA mapping was made for the same areas as those for color measurements (Fig. 3). Iron-distributions in 


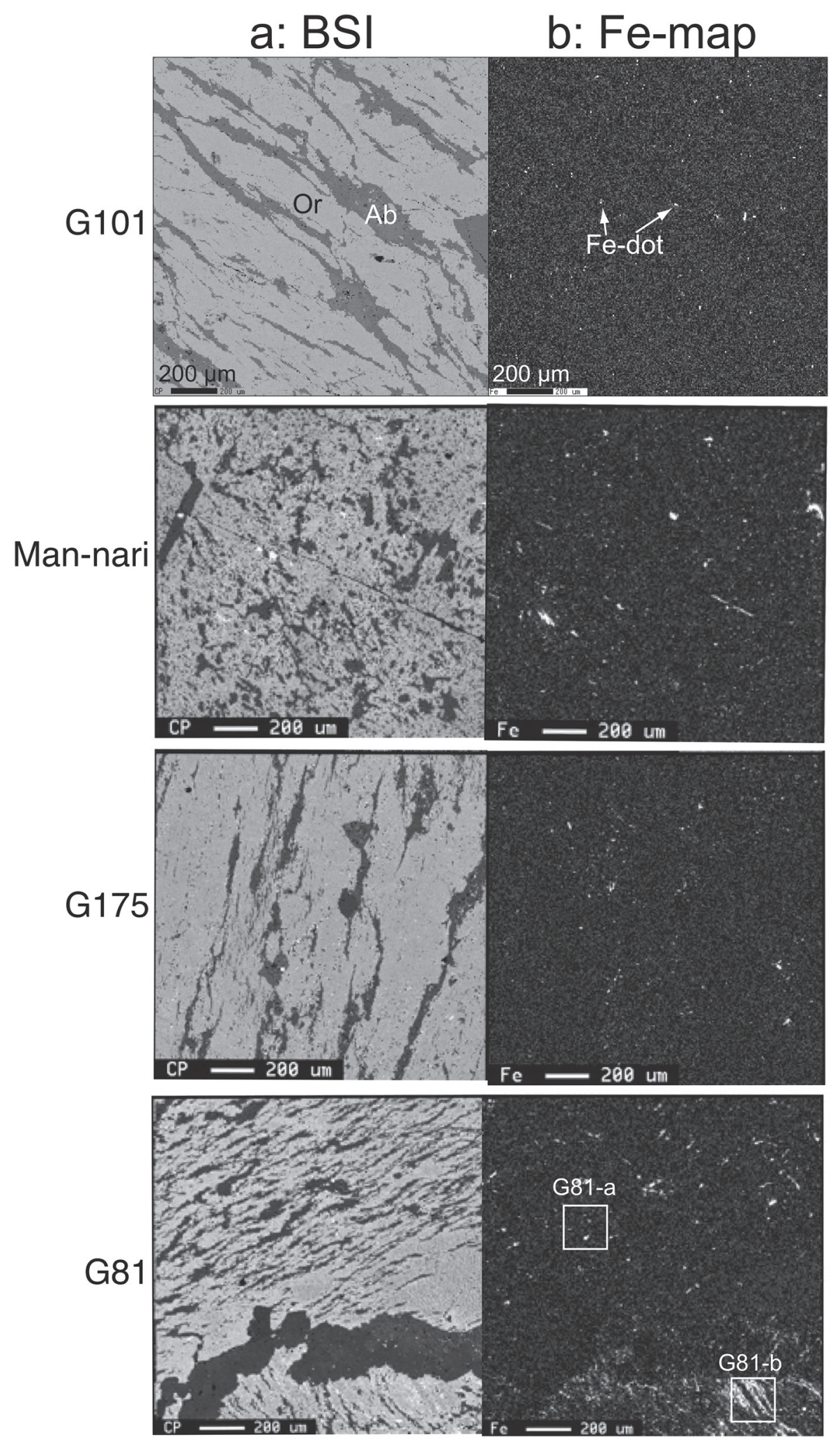

Fig. 3. (a) Back-scattered electron images (BSIs) and (b) Fe maps of the four alkali feldspars in the areas shown in Fig. 1a. Or: Or-rich alkali feldspar (host phase) and $\mathrm{Ab}$ : Ab-rich patch or vein (guest phase).

these areas are shown in Figure 3b, in which small Feenriched part appear dominantly as dots (Fe-dots). One pixel in the maps of Figure 3 corresponds approximately to a square with one side of $5.2 \mu \mathrm{m}$. Fe-dots are heterogeneously distributed in the alkali feldspar in Figure 3-b. The size of iron-bearing particles, probably ironoxide particles, is much variable from nm-size to $\mu \mathrm{m}$ size in individual feldspars. The employed step of ca. $5 \mu \mathrm{m}$ with a focused beam (around or somewhat below 1 $\mu \mathrm{m}$ in diameter) in the EMPA mapping did not detected 
Table 6. Semi-quantitative estimation of area proportions of Fe-dots and micropores, which were obtained by the following procedures using a JEOL SP VIEW software for the images of Fe-maps shown in Figure. $3 \mathrm{~b}$ and corresponding BSIs (Fig. 3a) respectively. Micropores appear as nearly no electron-emission areas. The maps are processed to the same maximum intensity and to the same separated intensity ranges in the Fe-maps and BSE-maps individually. Area proportions of Febearing particles were estimated using the uppermost intensity range in the Fe X-ray emission intensity histograms according to the criteria described in the text. Area proportions of micropores were estimated using the lowermost range in the electron emission intensity histogram.

\begin{tabular}{lrrrr}
\hline & G101 & Man-nari & G175 & G81 \\
\hline (a) Fe-dots & 0.4 & 1.2 & 0.5 & 2.3 \\
(b) Micropores & 1.9 & 4.1 & 0.4 & 0.9 \\
(a)/(b) & 0.2 & 0.3 & 1.3 & 2.6 \\
\hline
\end{tabular}

such particles in the gap areas between the steps. And, the Fe-dots are not necessarily of individual single grains, and may be aggregates of nm-size iron-oxide particles.

$\mathrm{Fe}$-dots in Figure $3 \mathrm{~b}$ are probably correspond to pixels of $\mathrm{Fe}_{2} \mathrm{O}_{3}$ higher than $0.1 \mathrm{wt} \%$ of the dominant matrix or background areas, apart from the problem of existing states of $\mathrm{Fe}_{2} \mathrm{O}_{3}$. The successive variation of Fe-dot quantities through the four maps is not clear in Fig. 3b. This is due to the deviated situation of the Fe-distributions of the Man-nari alkali feldspar, which disturbs the trends of visual colors through the four feldspars shown in Figure 1.

The area proportions of Fe-dots on individual maps were estimated by image processing using the JEOL software as shown in Table 6, whose procedure is described in its caption. Such semi-quantitative data are shown in the column (a) of Table 6. The NIH image processing was practically hard to apply to Fe-bearing particles differently from the case of micropores mentioned later, because large areas for statistical stability, which are needed owing to their actual low number densities, result in the low-precision for the area proportions of Fe-dots.

\section{Microscopic observations}

The alkali feldspars were observed under a binocular microscope (Fig. 4). Figure 4 individually displays representative close-up textures of the four reddish feldspars. Deeply reddish particles are vaguely seen in Figure 4, which is due to reddish colors of surrounding matrix (background) part. Such microscopic reddish particles correspond to Fe-dots in Figure 3b, and they are present in the areas of higher $\mathrm{Fe}_{2} \mathrm{O}_{3}$ contents probably above $0.1 \mathrm{wt} \%$ (Table 5). The matrix areas in Figure 4 are approximately the background part in Figure 3b, which corresponds to the areas of lower $\mathrm{Fe}_{2} \mathrm{O}_{3}$ contents probably below $0.1 \mathrm{wt} \%$ (Table 5). Figure 4 suggests with Figure $1 b$ that the reddish colors of the matrix part are due to the presence of much finer reddish particles, which are probably the same as the microscopic reddish particles.

\section{Raman spectroscopy}

Raman spectra obtained for selected small reddish particles or Fe-dots such as shown in Figures 3 and 4 respectively in the polished surfaces are shown in Figure 5. The peak intensities in Figure 5 are independent of the depths of the reddish colors or the values of $\mathrm{a}^{*}$ and $b^{*}$ in Figure 2 and Table 3. Raman peak intensities are affected by several factors that may be derived from Raman scattering mechanism of small measured particles by a small beam size of $c a .2 \mu \mathrm{m}$. Apart from such problem, all the spectra show the common presence of Fe-oxides as hematite $\left(\alpha \mathrm{Fe}_{2} \mathrm{O}_{3}\right)$ in the four feldspars, and the partial presence of maghemite $\left(\gamma \mathrm{Fe}_{2} \mathrm{O}_{3}\right)$ with hematite only in the G175 alkali feldspar.

\section{Micropores}

The genesis of micropores causing cloudiness and turbidity in feldspars is derived from the volume difference of cryptoperthite-constituting high-temperature feldspar phases and microperthite-constituting low-temperature feldspar phases (Parsons, 1978; Parsons and Brown, 1984; Smith and Brown, 1988; Worden et al., 1990; Guthrie and Veblen, 1991; Brown and Parsons, 1994; Deer et al., 2001; Hashimoto et al., 2005; Parsons and Lee, 2009; Parsons et al., 2013; etc.). Abundant micropores with microperthites are evidence of dissolution-reprecipitation reactions during the water-mediated perthite coarsening from cryptoperthites to microperthites (Putnis, 2002, 2009; Putnis and Putnis, 2007; Niedermeier et al., 2009; Norberg et al., 2011, 2013).

The present alkali feldspars commonly showing microperthitic textures are clouded to the naked eye (Fig. 1) and turbid under a microscope, which are indicative of hydrothermal perthite coarsening mentioned above. The white cloudiness of feldspars is due to the scatter- 


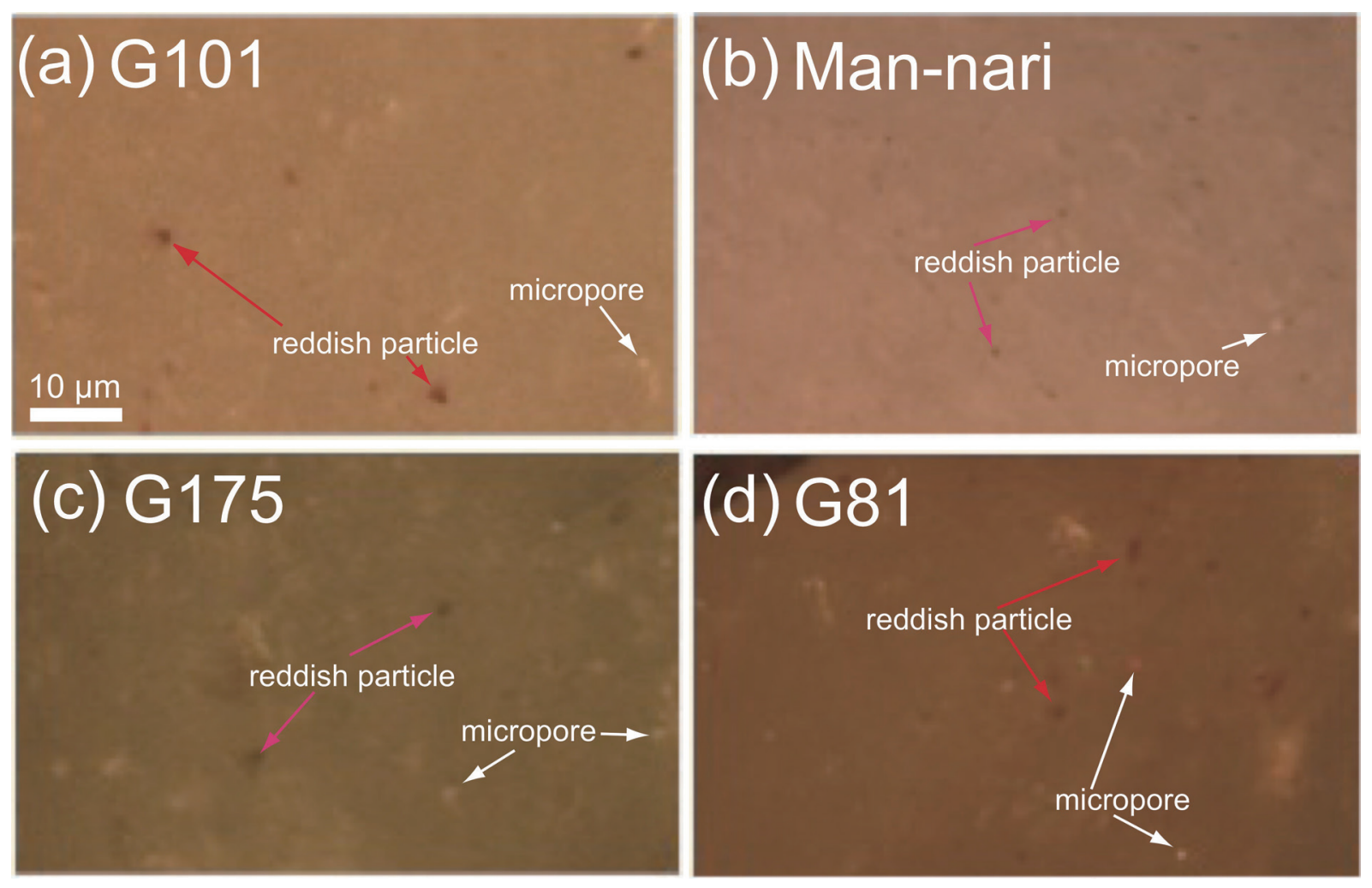

Fig. 4. Photomicrographs of the four reddish alkali feldspars under a binocular microscope. The photographs were taken to include both reddish particles and micropores in each sample so that the individual areas are independent of the areas shown in Figures 1 and 3. The observed reddish particles and micropores are much larger and less abundant than those in the matrix.

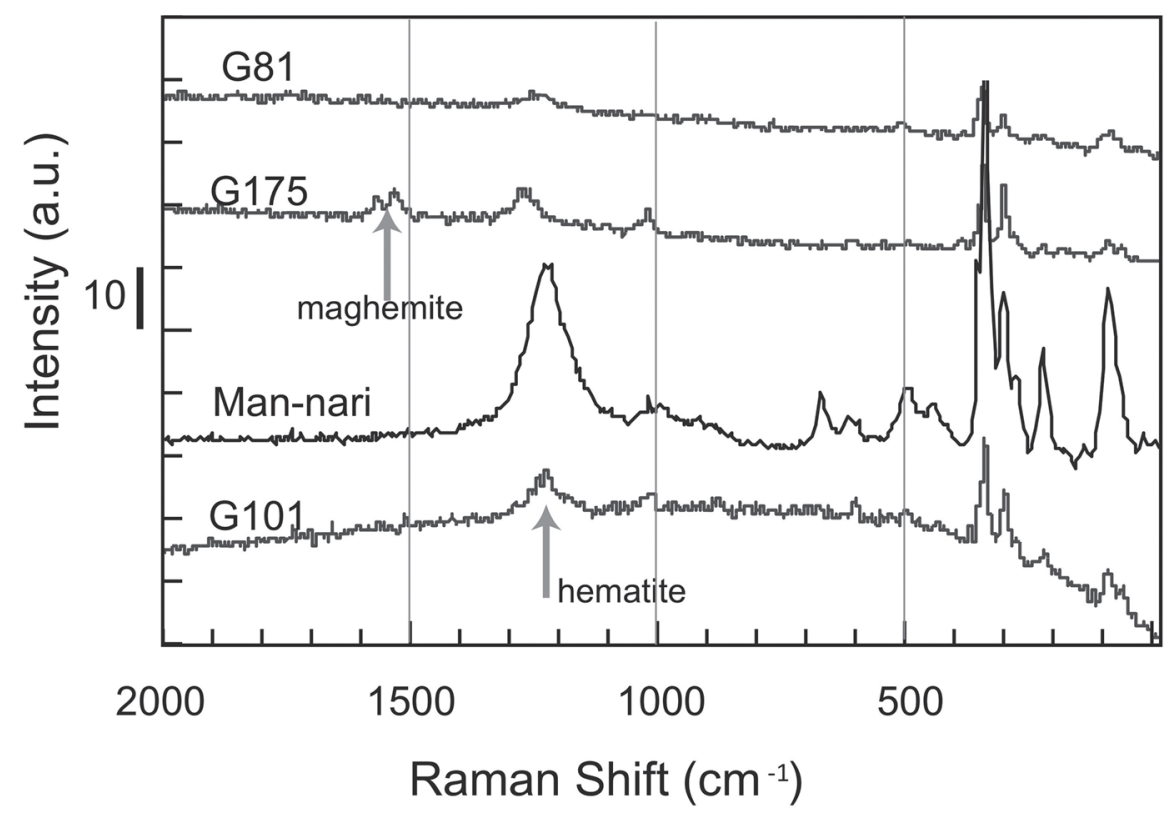

Fig. 5. Raman spectra of the four alkali feldspars. Analyzed particles were a range of sizes, so the different sizes of the four hematite peaks are not meaningful. a.u. = arbitrary unit. 


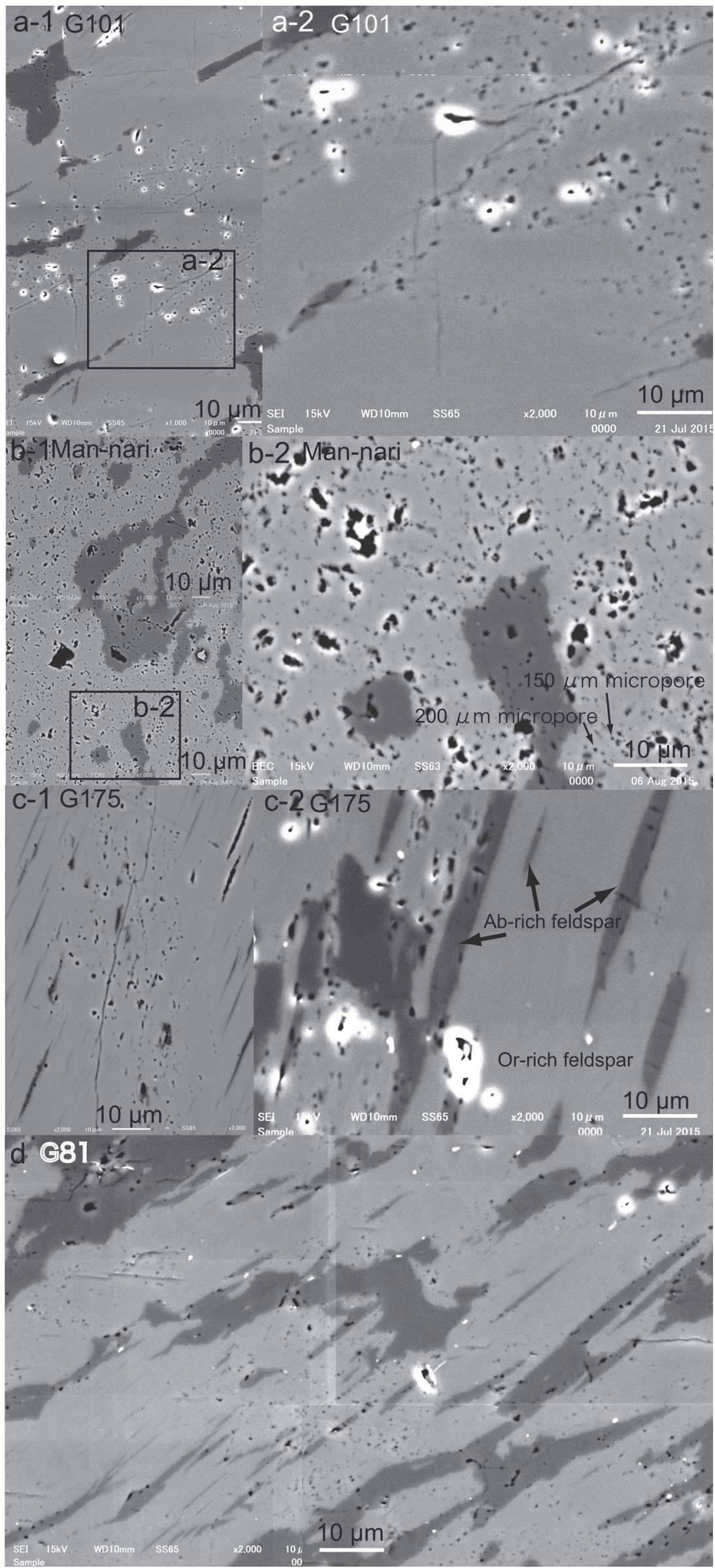

Fig. 6. (a, c, d) Secondary electron images and (b) BSI showing the size and distribution of nm-size micropores in the four alkali feldspars. Black dots are micropores, bright areas are Or-rich host feldspars, and grey areas are Ab-rich guest feldspars, as exemplified in (b-2) and $(\mathrm{c}-2)$. 
(a)

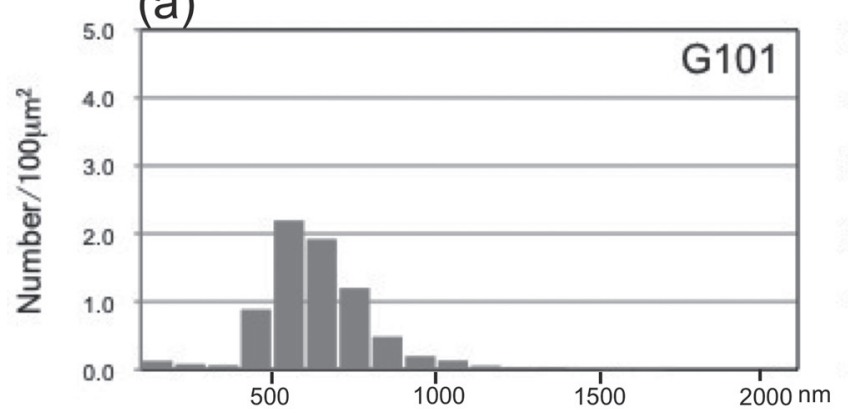

(c)

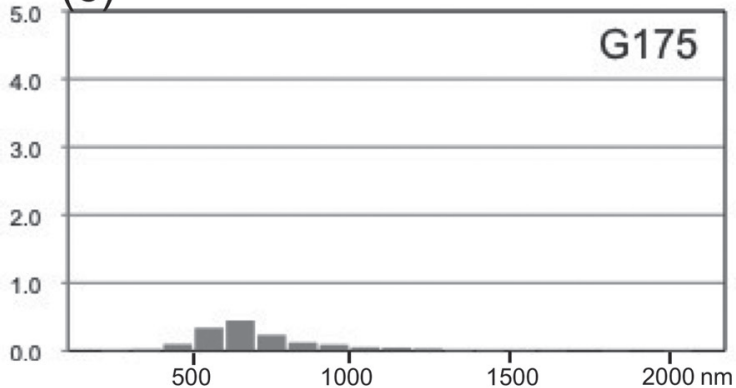

(b)

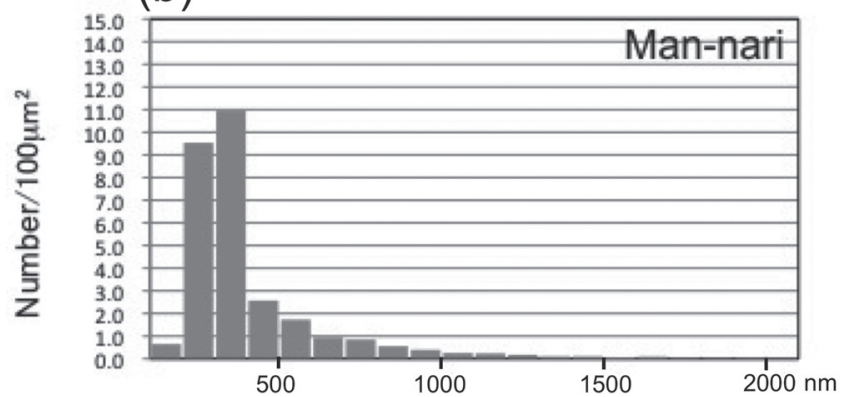

(d)

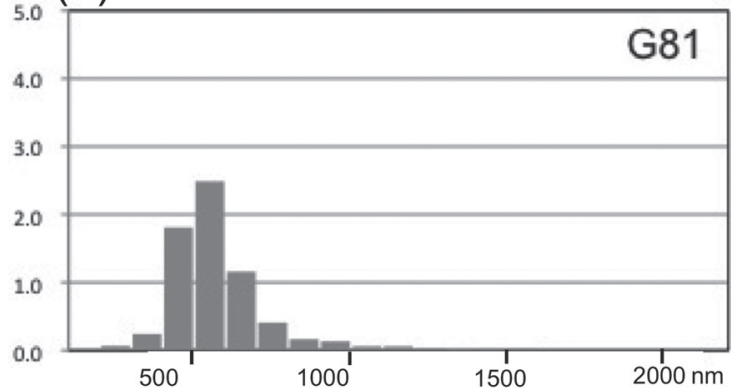

Fig. 7. Size distributions of micropores in the four reddish alkali feldspars: (a) G101, analyzed area: $307.7 \times 307.7 \mu \mathrm{m}$; (b) Man-Nari, two analyzed areas: $55.4 \times 55.4 \mu \mathrm{m}$ and $156.7 \times 156.7 \mu \mathrm{m}$; (c) G175, analyzed area: $270.0 \times 270.0 \mu \mathrm{m}$; and G81, analyzed area: $234.2 \times 234.2 \mu \mathrm{m}$. The Man-nari data are weighted averages of micropore-dense and micropore-sparse areas.

ing effect derived from the presence of many micropores of submicron size, which are produced by hydrothermal reaction (Ferry, 1985; Worden et al., 1990; Walker et al., 1995). Walker et al. (1995) already reported detailed characters of such micropores in alkali feldspars from granitic rocks. They defined micropores as having a general size smaller than $1 \mu \mathrm{m}$ in width, although slightly larger micropores are more or less associated. Most of them are around $0.5 \mu \mathrm{m}$, and the porosities are in the range from 0.40 to 2.87 except for that of 4.60 (Walker et al., 1995).

Micropores are recognized as fine whitish spots under a binocular microscope as shown in Figure 4, although they are vaguely recognized due to intense reddish colors of the surrounding matrix. On the other hand, micropores are recognized as black non-scattering areas (or dots) on BSIs and SEIs (Figs. 3a, 6). Semi-quantitative estimation of area proportions of micropores on the BSIs, which were obtained by image processing using the JEOL software, are shown in the row (b) of Table 6. In Figure 3a showing microperthitic textures, however, their presence is not well recognized due to the smallsize display of the four originally large-scale or lowmagnification images. This difficulty is actually solved in high-magnification images as shown in Figure 6.

High-magnification FE-SEM observations distinguish micropores at least around $100 \mathrm{~nm}$ in size (diameter) as shown in Figure 6. The size distribution and number density of micropores of nm-size in the alkali feldspars were obtained by image processing using the software (Image J, NIH) for the FE-SEM images (magnification $=1000$ or 2000 depending on their sizes and distributions) (Fig. 7). Figure 7 clearly shows the size distribution and number density of micropores of nm-size in the four alkali feldspars respectively, which is consistent with the results of Walker et al (1995).

As understood in Figures 6 and 7, the size distribution and number density of micropores are different each other between the four alkali feldspars, as well as those of Fe-bearing particles described already. Micropores are mostly in the diameter range between $400-800 \mathrm{~nm}$ with relatively moderate number densities around 1/100 $\mu \mathrm{m}^{2}$ in the G101 alkali feldspar, between $200-400 \mathrm{~nm}$ with relatively much larger number densities around $10 / 100 \mu \mathrm{m}^{2}$ in the Man-nari alkali feldspar, between 500-800 nm with relatively much smaller number densities around $0.3 / 100 \mu \mathrm{m}^{2}$ in the G175 alkali feldspar, and between $400-800 \mathrm{~nm}$ with relatively moderate number densities around $1.5 / 100 \mu \mathrm{m}^{2}$ in the G81 alkali feldspar. It is contrastingly noted in Figure 7 that micropores are relatively small and abundant in the Man-nari feldspar, and are relatively large and scarce in the G175 
feldspar.

\section{Discussion}

Two individual sets of $\mathrm{a}^{*}$ and $\mathrm{b}^{*}$ values for areas of 8 $\mathrm{mm}$ in diameter of pink and red granite blocks (Nakashima et al., 1992) are rather evenly plotted with small deviations in the lower and narrower range than the present data in Figure 2. The color data of the granite blocks are different from those of the present alkali feldspars. The large unevenness and wide distributions of the present color data through the four samples are a result of color measurements for much finer areas of $0.125 \mathrm{~mm} \times 0.125 \mathrm{~mm}$ solely in the alkali feldspar grains.

The S obtained in this study is approximately consistent with those of not only the fitting line for the color variation of reddish granite blocks, but also that of hematite-alumina mixture powders as shown in Figure 2 (Nakashima et al., 1992). In fact, the Raman spectra (Fig. 5) show the common presence of hematite in the alkali feldspars. The Raman spectrum of the G175 alkali feldspar shows the partial presence of maghemite with hematite. Such partial presence of maghemite is natural due to plausible transformation reactions between hematite and maghemite (e.g., Deer et al., 1952; Machala et al., 2011). The color of maghemite particles is brown (e.g., Deer et al., 1952; Machala et al., 2011). The tints of reddish colors owing to hematite particles are variable depending on their size, especially of $n m \sim \mu m$. Their reddish colors in individual areas or pixels are also affected by their distributions. To say in summary, the reddish color variations in the alkali feldspars principally depend on the size distribution and number density mainly of hematite (Figs. 6, 7), apart from the partial presence of maghemite. The inconsistency between the present color variation in Figures 1 and 2 and the $\mathrm{Fe}_{2} \mathrm{O}_{3}$ contents in Table 4 is reasonably interpreted by this important factor.

On the other hand, micropores are the cause of visual whiteness (whitish cloudiness) by light scattering as already mentioned. Many micropores of submicron size (nm-size) are heterogeneously distributed in the individual alkali feldspars (Figs. 6, 7). Therefore, it is deduced that the present feldspar reddish colors are thinned by whitish colors due to the presence of micropores. The degrees of such thinning depend on the size distribution and number density of micropores. This is another factor or influence on the inconsistency between the color variation and $\mathrm{Fe}_{2} \mathrm{O}_{3}$ contents in the four feldspars. After all, it is concluded that the color variation trend in Figure 2 results principally from variable combinations of the above two factors controlling reddish and whitish colors. Thus, the peculiarity of the Man-nari alkali feldspar as already described is interpreted to be a result of its intense whitish color due to abundant micropores overcoming its reddish colors due to abundant Fe-bearing particles. Semi-quantitative estimation in the column (c) of Table 6 supports this interpretation, showing that the areal proportions of Fe-dots to micropores increase consistently with the present color variation.

The fitting line for the present color variation on the $a^{*}-b^{*}$ diagram does not pass the origin $\left(a^{*}=0\right.$ and $b^{*}=$ 0) (Fig. 2), as well as the color variation of hydrothermally altered reddish granites (alkali feldspars) (Nakashima et al., 1992). The present I value $(=10.5)$ is raw without calibration, but there remains some plus value $(=4.2)$ in it even after a calibration by the subtraction of the $(\mathrm{b})$ value $(=7.11)$ from the $(\mathrm{a})$ value $(=$ 13.47) in Table 1. The corresponding value of Nakashima et al. (1992) is approximately 7. Both the plus b* values mean some addition of yellowish tint to the simple hematite-controlling color variation trend of powder samples (Nakashima et al., 1992). This deviation or shift is common independently of the difference of color measurement methods.

This cause is not clear at present in the four examined alkali feldspars. Nagano and Nakashima (1989) and Nakashima et al. (1992) referred the above shift to the presence of geothite $(\alpha \mathrm{FeOOH})$ and/or the presence of ferrihydrite. In addition, the presence of maghemite $\left(\gamma \mathrm{Fe}_{2} \mathrm{O}_{3}\right)$ newly found in this study is another contributor to it. Genetic relations and transformation processes between modifications of $\mathrm{Fe}_{2} \mathrm{O}_{3}$ and $\mathrm{FeOOH}$ are complicated and problematic (e.g., Majzlan et al., 2003; Machala et al., 2011). Further geochemical investigations of Fe behaviors in relation to feldspar reddening are needed to solve this problem.

At last, we mention the significance of the genetic processes of micropores and Fe-oxides. Micropores in the turbid microperthites of the four samples are considered to have been produced at the hydrothermal stage forming microperthites from the recent studies as already mentioned (Parsons, 1978; Worden et al., 1990; Walker et al., 1995; Hashimoto et al., 2005; Nakano et al., 2001; Parsons et al., 2013; Putnis, 2002). The origin of fluids or solutions of variable characters at the hydrothermal stage is either deuteric (intra-crystalline or local) or hydrothermal (metasomatic or large-scale). This problem individually needs further detailed studies by different standpoints. The hematite formation is also recognized to be secondary at the above hydrothermal stage from the above textural evidence and recent de- 
tailed studies as already mentioned (Putnis et al. 2007; Engvik et al., 2008; Plümper and Putnis, 2009), although several origins were proposed (Deer et al., 1952; Smith, 1974; Hofmeister and Rossman, 1983; Rawat et al., 1996). The formation of such secondary hematite has been recently supposed to be products of metasomatic iron-bearing fluid-feldspar interaction in larger scales up to a crustal one (Putnis et al. 2007; Engvik et al., 2008; Plümper and Putnis, 2009; Mondal et al., 2017). The genetic process of the Fe-oxides in the four examined samples also needs individual future studies from geological or petrological viewpoints. Apart from these problems, however, this study should provide new basic insights and information to future studies of alkali feldspar reddening in granitic rocks.

\section{Concluding remarks}

The color measurements using a new and simple method were made for four reddish alkali feldspars showing a successive color variation from pale pink to red. Raman spectroscopy shows the common presence of hematite particles in the four feldspars, and partial presence of maghemite in the G175 feldspar. It is confirmed by this study that the reddish colors in each sample is caused by the size distribution and number density of such Fe-oxide particles, although contents of $\mathrm{Fe}_{2} \mathrm{O}_{3}$ in the feldspars are not so consistent with the color variation. And, it is also confirmed that the white colors are caused by the size distribution and number density of micropores scattering light. After all, the actual and visible reddish colors in the feldspars are determined by variable combinations of the two factors controlling reddish and whitish colors, with the additional factor controlling variable yellowish tints probably caused by the combined size distributions and number densities of maghemite or plausible hydroxide minerals such as goethite and ferrihydrite.

\section{Acknowledgements}

The Sekigahara Stone Company (Sekigahara Town, Gifu Prefecture, Japan) provided many granite samples. Dr. M. Taga of Ryukoku University also provided a valuable sample of the Man-nari granite. Mrs. A. Masumori helped our color measurements and joined the discussion. Dr. M. Kayama of Kobe University (present: the University of Tokyo) crosschecked the Raman spectra using the apparatus of Okayama University of Science. Many constructive comments by reviewers greatly contributed to the revision of the manuscript. Dr. A. Kamei, the associate editor, helpfully and constructively advised to revise the manuscript. We sincerely thank these persons.

\section{References}

Boone, G. M., 1969, Origin of clouded red feldspars: petrologic contrasts in a granite porphyry intrusion. Am. J. Sci., 267, 633-668.

Brown, W. L. and Parsons, I., 1994, Feldspars in igneous rocks. In Parsons, I., ed., Feldspars and their Reactions, NATO ASI Ser. C421, Kluwer Academic Publishing, Amsterdam, 449-499.

Deer, W. A., Howie, R. A. and Zussman, J., 1952, Rock-Forming Minerals Vol. 5, Non-Silicates. Longmans, Green and Co., Ltd., 371p.

Deer, W. A., Howie, R. A. and Zussman, J., 2001, Rock-Forming Minerals Vol. 4A, Framework Silicates: Feldspars (2nd. ed.). Geol. Soc. London, 972p.

Demarco, M. M., Oyhantcabal, P., Stein, K. J. and Siegesmund, S., 2013, Granitic dimensional stones in Uruguay: evaluation and assessment of potential resources. Environ. Earth Sci., 69, 1397-1438.

Engvik, A. N., Putnis, A., Fitz Gerald, J. D. and Austroheim, H., 2008, Albitization of granitic rocks: The mechanism of replacement of oligoclase by albite. Can. Mineral., 46, 14011415.

Ferry, J. M., 1985, Hydrothermal alteration of Tertiary igneous rocks from the Isle of Sky, Northwest Scotland, II. Granites. Contrib. Mineral. Petrol., 91, 283-304.

Gaeta, M., Giuliani, A., Perilla, S. and Misiti, V., 2013, Reddish metagranites from the Gennargentu Igneous Complex (Sardinia, Italy); Insight to metasomatism induced by magma mixing. J. Petrol., 54, 839-859.

Guthrie, G. D. Jr. and Veblen, D. R., 1991, Turbid alkali feldspars from the Isle of Skye, northwest Scotland. Contrib. Mineral. Petrol. 108, 298-304.

Hashimoto, K., Akai, J. and Nakano, S., 2005, Microtextures of alkali feldspar in the Tanakami granite, Southwest Japan and their formation processes. J. Mineral. Soc. Japan, 34, $1-14$. $^{*}$

Hofmeister, A. M. and Rossman, G. R., 1983, Color in feldspars. In Ribbe, P. H., ed., Feldspar Minerals, Reviews in Mineralogy, Mineralogical Society of America Vol. 2 (2nd ed.), 271-280.

Hunt, R. W. G., 1980, Color terms, symbols, and their usage. In Grum, F. and Barleson, C. J., eds., Optical Radiation Measurement, Academic Press, New York, 11-31.

Kohno, T., Nakano, S., Makino, K., Kayama, M. and Nishido, H., 2011, Photoluminescence of alkali feldspar measured with a portable CCD spectrometer. Japan. Mag. Mineral. Petrol. Sci., 105, 45-56. *

Lee, M. A. and Parsons, I., 1997, Dislocation formation and albitization in alkali feldspar from the Shap granite. Am. Mineral., 82, 557-570.

Machala, L., Tucek, J. and Zboril, R., 2011, Polymorphs transformations of nanometric iron(III) oxide: A review. Chem. Mater., 23, 3255-3272.

Majzlan, J., Grevel, K-D. and Navrotsky, A., 2003, Thermodynamics of Fe oxides: Part II. Enthalpies of formation and relative stability of goethite $(\alpha-\mathrm{FeOOH})$, lepidocrocite $(\gamma-\mathrm{FeOOH})$, and maghemite $\left(\gamma-\mathrm{Fe}_{2} \mathrm{O}_{3}\right)$. Am. Mineral., 88, 855-859.

Manaka, M., Fukushi, K., Miyashita, Y., Ito, J., Watanabe, Y., Kobayashi, K. and Kamei, A., 2012, Comparison of fault gauges in the aftershock area and the non aftershock area of the 2000 Tottori-ken Seibu earthquake. J. Geol. Soc. Japan, 118, 459-475.

Mondal, S., Upadhyay, D. and Banerjee, A., 2017, The origin of rapakivi feldspar by a fluid-induced coupled dissolution-re- 
precipitation process. J. Petrol., 58, 1393-1418.

Nagano, T. and Nakashima, S., 1989, Study of colors and degrees of weathering of granitic rocks by visible diffuse reflectance spectroscopy. Geochem. J., 23, 75-83.

Nakano, S., Akai, J. and Shimobayashi, N., 2005, Contrasting $\mathrm{Fe}-\mathrm{Ca}$ distributions and related microtextures in syenite alkali feldspar from the Patagonian Andes, Chile. Mineral. Mag., 69, 523-537.

Nakano, S., Akai, J. and Sugaki, A., 2002, Fluorite particles inducing butterfly aggregates of incipient microperthite in alkali feldspar from a syenite, the Patagonian Andes, southern Chile. Am. Mineral., 87, 1377-1383.

Nakano, S., Kutsukake, T. and the Collaborative Research Group for the Granites around Lake Biwa, 2014, Hydrothermal reconstruction of the granitoids: As inferred from the mineralogy of the two contrasting Cretaceous granitoid plutons, west to Lake Biwa, Japan. Japam. Mag. Mineral. Petrol. Sci., 43, 184-199.*

Nakano, S., Makino, K. and Eriguch, T., 2001, Microtexture and water content of alkali feldspar by Fourier-transform infrared microspectrometry. Mineral. Mag., 65, 675-683.

Nakano, S. and Makino, K., 2010, Amazonitic alkali feldspar from the Tanakami Granitic pegmatite, southwest Japan. $J$. Mineral. Petrol. Sci., 105, 45-56.

Nakano, S., Masumori, A., Kohno, T., Sawada, K., Maniwa, K. and Makino, K., 2012, Color measurement of minerals by a new method using a personal computer and a scanner. Mem. Fac. Educ. Shiga Univ., 62, 47-65. *

Nakashima, S., Miyagi, I., Nakata, E., Sasaki, H., Nittono, S., Hirano, T., Sato, T. and Hayashi, H., 1992, Color measurement of some natural and synthetic minerals-I. Rep. Res. Inst. Nat. Resour., Min. Coll., Akita Univ., 57, 57-76. *

Nakashima, S., Ohki, S. and Ochiai, S., 1989, Infrared microspectroscopy analysis of the chemical state and spatial disutribution of hydrous species in minerals. Geochem. J., 23, $57-64$.

Niedermeier, D. R. D., Putnis, A., Geisler, T., Golla-Schindler, U. and Putnis, C. V., 2009, The mechansim of cation and oxygen isotope exchange in alkali feldspars under hydrothermal conditions. Contrib. Mineral. Petrol., 157, 65-76.

Norberg, N., Harlov, D., Neusser G., Wirth, R., Rhede, D. and Morales, L., 2013, Experimenntal development of patch perthite from synthetic cryptoperthite: Microtextural evolution abd chemical re-equilibration. Am. Mineral., 98, 14290-1441.

Norberg, N., Neusser, G., Wirth, R. and Harlov, D., 2011, Microtextural evolution during experimental albitization of Krich alkali feldspar. Contrib. Mineral. Petrol., 162, 531-546.

Parsons, I., 1978, Feldspars and cooling plutons. Mineral. Mag., 42, 1-17.

Parsons, I. and Brown, W. L., 1984, Feldspars and the thermal history of igneous rocks. In Brown, W. L., ed., Feldspars and Feldspathoids, NATO Science Series. C137, D. Reidel
Publishing Company, Dordrecht, Holland, 317-371.

Parsons, I., Fitz Gerald, J. D., Heizler, M. T., Ivanic, T. and Lee, M. R., 2013, Eight-phase alkali feldspars: low-temperature cryptoperthite, peristerite and multiple replacement reactions in the Klokken intrusion. Contrib. Mineral. Petrol., 165, 931-960.

Parsons, I. and Lee, M. R., 2009, Mutual replacement reactions in alkali feldspars I: microtextures and mechanism. Contrib. Mineral. Petrol., 157, 641-661.

Plümper, O. and Putnis, A., 2009, The complex hydrothermal history of granitic rocks: Multiple feldspar replacement reactions under subsolidus conditions. J. Petrol., 50, 967-987.

Putnis, A., 2002, Mineral replacement reactions: from macroscopic observations to microscopic mechanisms. Mineral. Mag., 66, 689-708.

Putnis, A., 2009, Mineral replacement reactions. In Oelkers, E. H. and Schott, J., eds., Thermodynamics and Kinetics of Water-Rock Interaction, Rev. Mineral. Geochem., 70, Mineral. Soc. Am., 87-124.

Putnis, A. and Putnis, C. V., 2007, The mechanism of reequilibration of solids in the presence of a fluid phase. J. Solid State Chem., 180, 1783-1786.

Putnis, A., Hinrichs, R., Putnis, C. V., Golla-Schindler, U. and Collins, L. G., 2007, Hematite in porous red-clouded feldspars: Evidence of large-scale crustal fluid-rock interaction. Lithos, 95, 10-18.

Rawat, R.S., Kumari, P., Pandey, B. K. and Nautiyal, S. P., 1996, Origin of pink K-feldspars in the Peraluminous Amritpur granite, Lesser Kumaun Himalaya, India. Neues Jahrb. Mineral. Mittailungen, H.1, 9-20.

Sekigahara Stone Company, 1998, The Earth Work (Catalogue to Order, Vol. 1). 256p.

Smith, J. V., 1974, Feldspar Minerals 2, Chemical and Textural Properties, Springer-Verlag Berlin Heidelberg New York, $690 \mathrm{p}$.

Smith, J.V. and Brown, W.L., 1988, Feldspar Minerals, I. Crystal Structure, Physical, Chemical, and Microtextural Properties, Springer-Verlag, Berlin, 828p.

Walker, F. D. L., Lee, M. R. and Parsons, I., 1995, Micropores and micropermeable texture in alkali feldspars: geochemical and geophysical implications. Mineral. Mag., 59, 505534.

Worden, R., Walker, F. D. L., Parsons, I. and Brown, W. L., 1990, Development of microporosity, diffusion channels and deuteric coarsening on perthitic alkali feldspars. Contrib. Mineral. Petrol., 104, 507-514.

Yoshida, I., Sakashita, F., Makino, S. and Nakano, S., 2010, Microtexture's contribution to the coloring of alkali feldspars from the Man-nari and Ariake granites (abstract). Abstr. Annu. Meet. Japan. Soc. Mineral., 102. **

*: in Japanese with English abstract

**: in Japanese 
(要 旨)

Nakano, S., Makino, K., Yoshida, I., Maniwa, K., Sawada, K., Sakashita, F. and Kohno, T., 2019, Combined influences of iron-oxides and micropores on reddish coloration of alkali feldspars in granitic rocks. J. Geol. Soc. Japan, 125, 759-773. (中 野聰志・牧野州明・吉田 泉 - 真庭香奈恵 - 澤田一彦・坂下風子・河野俊夫 · 花崗岩赤色 系アルカリ長石における色変化の複合要因. 地質雑, 125, 759-773.)

系統的な色変化を示す花崗岩中赤色アルカリ長石 4 種について, 国際的色表示パラメー ターである $\mathrm{L}^{*}, \mathrm{a}^{*}, \mathrm{~b}^{*}$ を，パソコンとスキャナーによる新しい簡便な方法で求めた. 得 られた $\mathrm{a}^{*}-\mathrm{b} *$ 図上での 4 試料を通しての色変化に対する回帰直線は、赤鉄鉱含有量支配の 色変化に対比できる. 反射顕微鏡と EMPA 観察により，微細赤色含鉄粒子とともに白色要 因であるマイクロポアの存在を確認した. ラマンスペクトル解析により，これらの赤色粒 子は赤鉄鉱と一部マグへマイトであることが判明した. 反射電子線像とその画像解析によ り，微細鉄酸化鉱物粒子とマイクロポアについての分布パターンとそれらの含有割合 (面積 比）を見積もった. これらのデータは，今回のアルカリ長石色変化が，主として酸化鉄鉱物 が寄与する赤色要因とマイクロポアのサイズ分布と数密度が寄与する白色要因の両方に支 配されていることを示している. 